\title{
Evaluation of Environmental Heat Stress on Physical and Hormonal Parameters in Murrah Buffalo
}

\author{
Birendra Kumar ${ }^{2}$, Ajit Kumar Sahoo ${ }^{2}$, Pradeep Kumar Ray ${ }^{1}$, P C Chandran ${ }^{1}$, Subhash \\ Taraphider ${ }^{2}$, Ananta Kumar Das ${ }^{2}$, Subhasis Batabyal ${ }^{2}$, Shanker Dayal ${ }^{1 *}$ \\ ${ }^{1}$ ICAR Research Complex for Eastern Region, Patna-800014; ${ }^{2}$ West Bengal Animal and Fishery Science University, \\ Belgachia, Kolkata, India.
}

\begin{abstract}
Buffaloes have poor heat tolerance capacity compared to other domestic ruminants and are more prone to heat stress due to scarcely distributed sweat glands, dark body color and sparse hair on the body surface. Thermal environment is a major factor that can affect milk production and reproduction in buffalo especially animals of high genetic merit. Therefore present study was undertaken to study the effect of seasonal stress on Murrah buffalo. Thirty healthy non-lactating Murrah buffaloes each around two years of age were selected for the experiment. Rectal temperature, respiration rate, heart rate and various hormones level were measured in different season to know the effect of heat stress in buffalo. Season had no significant effect on rectal temperature, triiodothyronine (T3) and thyroxine (T4) level. However, it had significant effect on respiration rate $(\mathrm{P} \leq 0.05)$, heart rate $(\mathrm{P} \leq 0.01)$ and cortisol level $(\mathrm{P} \leq 0.05)$ in Murrah buffalo. They had lowest level of respiration rate, heart rate and cortisol level in winter season and highest level in summer. This indicates stressful condition of animal in summer.
\end{abstract}

Keywords | Buffalo, Heat stress, Season, Temperature humidity index, Hormone

Editor | Asghar Ali Kamboh, Sindh Agriculture University, Tandojam, Pakistan.

Received | January 03, 2019; Accepted | February 03, 2019; Published | February 23, 2019

*Correspondence | Shanker Dayal, ICAR Research Complex for Eastern Region, Patna-800014, India; Email: antudayal@gmail.com

Citation | Kumar B, Sahoo AK, Ray PK, Chandran PC. Taraphder S, Das AK, Batabyal S, Dayal S (2019). Evaluation of environmental heat stress on physical and hormonal parameters in murrah buffalo. J. Anim. Health Prod. 7(1): 21-24.

DOI | http://dx.doi.org/10.17582/journal.jahp/2019/7.1.21.24

ISSN $\mid 2308-2801$

Copyright (c) 2019 B-Kumar et al. This is an open access article distributed under the Creative Commons Attribution License, which permits unrestricted use, distribution, and reproduction in any medium, provided the original work is properly cited.

\section{INTRODUCTION}

$\mathrm{B}$ ihar is an agrarian state which has predominantly subtropical climatic region. It experiences fairly low temperatures in winters and high temperatures in summers. Since these climatic conditions leads to discomfort and stress in livestock population, their productivity is reduced. The livestock becomes incapable to achieve their genetic potential and therefore exhibits poor reproductive and productive performances (Kumar VS et al., 2018). Heat stress occurs in animal when there is an imbalance between heat production within the body and its dissipation. Considerable variation exists for heat tolerance between individual species/breeds and even between individual within a species/breeds. Akari et al. (1984) found that body temperature of dairy cattle shows susceptibility to hot weather, therefore it can be used as sensitive indicator of heat stress. Mcdowell et al. (1976) also suggested that temperature humidity index (THI) could be used as indicator of thermal climatic condition. THI value of 72 is considered comfortable, $72-78$ stressful and values greater than 78 causes extreme distress in lactating animal being animal unable to maintain normal body temperature. A rise of $1^{\circ} \mathrm{C}$ or less in rectal temperature is enough to reduce performances in most livestock species (McDowell et al., 1976). Respiration rate is increased when the environmental temperature increases. An evaporative heat loss from respiratory tract is regarded as one of the primary mechanism of heat balance. A high respiration rate in most cases did not necessarily indicate that the animal is successful in keeping its body temperature constant but rather indicated that it is already overheated and trying to restore normal heat balance. Lemerle and Goddard (1986) reported that, although rectal temperature increases only when THI was greater than 80 , the respiration rate would begin to increase above a THI value of about 73 and would prob- 
ably increase steeply at THI values 80 . This finding suggests that homeostatic mechanisms, including increased respiration, can prevent a rise in rectal temperature until the THI reaches 80 .The general homeostatic responses to thermal stress in mammals include reduction in fecal and urinary water losses, reduction in feed intake and production, and increased sweating, as well as initial increases in respiratory rates and heart rates, which would slow down if heat stress persists. In response to stress, the dairy cow sets physical, biochemical, and physiological processes into play to try and counteract the negative effects of heat stress and maintain thermal equilibrium. Heat stress activates the hypothalamo-pituitary-adrenal cortical axis (HPA) and sympatho-adrenal medullary axis. This leads to increase in plasma concentration of cortisol in heat stressed animals (Minton, 1994). Magdub et al. (1982) reported that heat stress leads to decreased concentrations of triiodothyronine (T3) and thyroxine (T4) in plasma and in milk of lactating cows. Chaudhary et al. (2015) also reported significant decrease in T3 level with increase in THI value in Surti buffalo. However, a significant increase in T3 but not in T4 level was observed during heat stress in crossbred cattle (Singh et al., 1984). Buffaloes have poor heat tolerance capacity compared to other domestic ruminants and are more prone to heat stress due to scarcely distributed sweat glands, dark body color and sparse hair on the body surface. Thermal environment is a major factor that can affect milk production and reproduction in buffalo especially animals of high genetic merit. Therefore present study was undertaken to evaluate the environmental heat stress on physical and hormonal parameters.

\section{MATERIALS AND METHODS}

\section{Experimental ANimal}

Thirty non lactating Murrah Buffalo of about 2 yr. age was selected from the herd maintained at institute's farm. The animals were maintained at standard manage mental condition with adlibitum access to feed and water.

\section{Climatic Measurements}

Minimum and maximum temperature, dry bulb and wet bulb temperature was measured daily at buffalo shed. Temperature humidity index (THI) was calculated as per Mcdowell et al. (1976). Experiment period was divided into 3 seasons, viz. spring (Mid February to Mid May), summer (Mid May to Mid August) and winter (mid November to mid February).

\section{Measurement of Rectal Temperature,} Respiration Rate and Heart Rate:

Rectal temperature was measured with the help of simple mercury thermometers daily both in the morning at 7 AM and evening at $4 \mathrm{PM}$ for all the animals included in the study. Respiration was also measured daily by silently observing the movement of the thoracoabdominal region for each animal included in the study. Heart rate is measured by observing pulse from coccygeal artery.

\section{Collection of Blood Sample}

Blood sample were collected from each experimental animal in three different seasons namely winter, spring and summer at 15 days interval. 1-2 $\mathrm{ml}$ of blood was collected from the jugular vein of each animal in a sterile polypropylene vials without adding anticoagulant for the isolation of serum /plasma for the evaluation of hormonal profile.

\section{Measurement of Hormonal Parameters}

Cortisol, triiodothyronine (T3) and thyroxine (T4) level in each season was measured by using ELISA kit (Monobind, USA) using manufacturer's protocol.

\section{Statistical Analysis of Data}

Data was computed and analyzed statistically according to methods of Snedecor and Cochran, (1994).

\section{RESULTS AND DISCUSSION}

The ambient temperature and Thermo humidity index (THI) prevailing during the experimental period is presented in Table 1. THI was found to be highest in summer and lowest in winter. The Livestock Weather Safety Index (LCI 1970) is commonly used as benchmark to assign heat stress levels to normal, alert, danger and emergency categories. In this index, THI $\leq 74$ is classified as normal, 75-78 as alert and $79-83$ as danger and $\mathrm{THI} \geq 84$ as emergency. Therefore based on this index buffaloes reared in summer falls under emergency category indicating stressful condition of the animal.

Table 1: Environmental parameters prevailing during the experiment.

\begin{tabular}{|llll|} 
Season & $\begin{array}{l}\text { Maximum } \\
\text { Temperature }\end{array}$ & $\begin{array}{l}\text { Minimum } \\
\text { Temperature }\end{array}$ & $\begin{array}{l}\text { Temperature } \\
\text { Humidity Index }\end{array}$ \\
\hline Spring & $30.37 \pm 2.36$ & $23.65 \pm 3.46$ & $68.56 \pm 6.94$ \\
Summer & $39.17 \pm 2.38$ & $28.82 \pm 1.32$ & $84.74 \pm 7.32$ \\
Winter & $22.81 \pm 1.42$ & $10.24 \pm 1.57$ & $53.86 \pm 4.38$ \\
\hline
\end{tabular}

Effect on Rectal Temperature, Respiration Rate and Pulse Rate

Rectal temperature, respiration rate and pulse rate measured during experimental period are presented in Table 2. Seasons had non significant effect on both morning and evening rectal temperature. However, both morning and evening rectal temperature was highest in summer and lowest in winter. Bhat et al. (2016) reported significant increase in both morning and evening rectal temperature 
in summer in Tharparkar cattle. Singh et al. (2014) also reported significant effect of season on rectal temperature in Murrah buffalo.

Table 2: Effect of season on rectal temperature, respiration rate and pulse rate of Murrah buffalo.

\begin{tabular}{lllll} 
Season & \multicolumn{2}{l}{$\begin{array}{l}\text { Rectal Temperature } \\
\text { Morning }\end{array}$} & $\begin{array}{l}\text { Rvening } \\
\text { rate }\end{array}$ & $\begin{array}{l}\text { Pulse } \\
\text { Rate }^{* *}\end{array}$ \\
Spring & $99.83 \pm$ & $100.15 \pm$ & $13.25 \pm$ & $63.79 \pm$ \\
& 0.07 & 0.17 & $0.46^{\mathrm{b}}$ & $1.03^{\mathrm{b}}$ \\
Summer & $101.1 \pm$ & $101.18 \pm$ & $18.97 \pm$ & $69.98 \pm$ \\
& 0.03 & 0.02 & $0.59^{\mathrm{c}}$ & $0.81^{\mathrm{c}}$ \\
Winter & $99.13 \pm$ & $99.37 \pm$ & $10.91 \pm$ & $58.52 \pm$ \\
& 0.04 & 0.08 & $0.50^{\mathrm{a}}$ & $2.21^{\mathrm{a}}$
\end{tabular}

*Different superscripts indicate significance at 5\% level

**Different superscripts indicate significance at $1 \%$ level

Season had significant effect $(\mathrm{P} \leq 0.05)$ on respiration rate. Respiration rate was found to be highest in summer $(18.97 \pm 0.59)$ and lowest in winter $(10.91 \pm 0.50)$. Increased respiration rate is the first reaction when animals are exposed to environmental temperature above thermoneutral zone. Das et al. (1999) also observed an increase in respiration rate in June in Murrah buffalo claves when exposed to direct sunlight for $6 \mathrm{hr}$. Bhat et al. (2016) also reported significant increase in respiration rate in summer in Tharparkar cattle.

Season had significant effect $(\mathrm{P} \leq 0.01)$ on heart rate. Heart rate was found to be highest in summer $(69.98 \pm 0.81)$ and lowest in winter $(58.52 \pm 2.21)$. Singh et al. (2014) also reported significant effect of season on heart rate in Murrah buffalo. However, they reported highest heart rate in winter $(73.43 \pm 4.21)$ and lowest in summer $(67.65 \pm 2.8)$.

\section{Effect of Season on Hormonal Assay}

Effect of seasonal stress was measured on cortisol, T3 and T4 levels and data were presented in Table 3.There was seasonal variation in T3 and T4 level. But this variation was statistically non significant. Level of T3 and T4 was higher in winter than the summer. Magdub et al. (1982) also reported similar result and observed that during heat stress, T3 and T4 levels in plasma and milk decreases. Chaudhary et al. (2015) also reported significant decrease in T3 level with increase in THI value. However, Singh et al. (1984) reported a significant increase in T3 but in T4 level during heat stress in crossbred cattle.

We observed significant effect $(\mathrm{P} \leq 0.05)$ of season on Murrah buffalo. Our study revealed much higher level of cortisol in summer $(6.54 \pm 0.67 \mathrm{ng} / \mathrm{ml})$ than the spring $(4.43 \pm 1.68 \mathrm{ng} / \mathrm{ml})$ and winter $(4.03 \pm 1.08 \mathrm{ng} / \mathrm{ml})$. This may be due to heat stress in summer activates the hypothalmo-pitutary-adrenal cortical axis (HPA) and sympa- tho-adrenal medullary axis (Minton, 1994). This increases the plasma concentration of cortisol and corticosterone. Higher concentration of cortisol level during heat stress was also reported by Comin et al. (2011).

In brief, these results demonstrated the significant effect of season on Murrah buffaloes. Summer season has a stressful effect on animals' physiological and hormonal parameters that may be overcome through well managed farming systems.

Table 3: Effect of season on hormone profile of Murrah buffalo.

\begin{tabular}{|llll} 
Parameter & Spring & Summer & Winter \\
\hline Cortisol $(\mathrm{ng} / \mathrm{ml})^{*}$ & $4.43 \pm 1.68^{\mathrm{b}}$ & $6.54 \pm 0.67^{\mathrm{a}}$ & $4.03 \pm 1.08^{\mathrm{c}}$ \\
T3 $(\mathrm{ng} / \mathrm{ml})$ & $2.15 \pm 0.58$ & $1.92 \pm 0.20$ & $2.72 \pm 0.84$ \\
$\mathrm{~T} 4(\mathrm{ng} / \mathrm{ml})$ & $32.86 \pm 1.07$ & $32.25 \pm 1.10$ & $35.39 \pm 1.07$
\end{tabular}

*Different superscripts indicate significance at $5 \%$ level

\section{ACKNOWLEDGEMENTS}

The authors are thankful to the Director, ICAR Research Complex for Eastern Region, Patna, Bihar for providing necessary facilities and financial support to carry out this work.

\section{CONFLICT OF INTEREST}

We declare that we have no conflict of interest.

\section{AUTHORS CONTRIBUTION}

This work is a part of PHD project work of first Author Dr. Birendra Kumar. Dr. A K Sahoo, Dr S. Taraphder, Dr. A K Das helped in statistical analysis and manuscript writing, Dr P K Ray provided technical help while conducting the experiment, Dr P C Chandran helped in maintaining the experimental animal and recording of Data, Dr Shanker Dayal planned, supervised the work and edited the manuscript.

\section{REFERENCES}

-Akari CT, Nakamura RM, Kam LWG, Clarke N (1984). The effect of level of lactation diurnal temperature patterns of dairy cattle in hot environments. J. Dairy Sci. 67: 1752-1760 https://doi.org/10.3168/jds.S0022-0302(84)81501-5.

- Bhat S, Kumar P, Kashyap N, Deshmukh B, Dighe MS, Bhushan B, Chauhan A, Kumar A, Singh G (2016). Effect of heat shock protein 70 polymorphism on thermotolerance in Tharparkar cattle. Vet. World. 9(2):113-117. https://doi. org/10.14202/vetworld.2016.113-117

- Chaudhary SS, Singh VK, Upadhyay RC, Puri G, Odedara AB, Patel PA (2015). Evaluation of physiological and biochemical responses in different seasons in Surti buffaloes. 
Vet. World. 8(6): 727-731. https://doi.org/10.14202/ vetworld.2015.727-731

- Comin A, Prandi A, Peric T, Corazzin M, Dovier S, Bovolenta S (2011). Hair cortisol levels in dairy cows from winter housing to summer highland grazing. Livest. Sci. 138: 6973. https://doi.org/10.1016/j.livsci.2010.12.009

-Das SK, Upadhayaya RC, Madan ML (1999). Heat stress in Murrah buffalo calves. Livest. Prod. Sci. 61: 71-78. https:// doi.org/10.1016/S0301-6226(99)00040-8

- Kumar VS, Kumar RP, Harikrishna CH, Rani MS (2018). Effect of heat stress on production and reproduction performance of buffaloes-A review. Pharma. Innovat. 7 (4) : 629-633.

- Lemerle C, Goddard ME (1986). Assesment of heat stress in dairy cattle in Papua New Guinea. Trop. Anim. Hlth. Prod. 18 : 232-242. https://doi.org/10.1007/BF02359540

-McDowell RE, Hooven NW, Camoens JK (1976). Effects of climate on performance of Holsteins in first lactation. J. Dairy Sci. 59: 965-73. https://doi.org/10.3168/jds.S00220302(76)84305-6
-Minton JE (1994). Function of the HPA axis and Sympathetic nervous system in models of acute stress in domestic farm animals. J. Anim. Sci.72: 1891. https://doi. org/10.2527/1994.7271891x

- Magdub A, Johnson HD, Belyea RL (1982). Effect of environmental heat and dietary fibers on thyroid physiology of lactatingcows. J. Dairy. Sci. 65: 2323-2331. https://doi. org/10.3168/jds.S0022-0302(82)82504-6

- Singh AK, Upadhyay RC, Malakar D, Kumar S, Singh SV (2014). Effect of thermal stress on HSP 70 expressionin dermal fibroblast of zebu (Tharparkar) and crossbred (KaranFries) cattle. J. Thermo. Biol. 43: 46-53. https://doi. org/10.1016/j.jtherbio.2014.04.006

- Singh K, Saxena SK, Mahapatro BB, Raja Nasir MM (1984). Annual Report of IVRI. Izatnagar. Pp 41-45.

- Snedecor GW, Cocharn WG (1994). Statistical methods. 6thedn. Oxford and IBH, Publishing Company, Calcutta. 